\title{
Marine coastal sediments microbial hydrocarbon degradation processes: contribution of experimental ecology in the omics'era
}

\section{Cristiana Cravo-Laureau and Robert Duran*}

Equipe Environnement et Microbiologie UMR IPREM 5254, Université de Pau et des Pays de I'Adour, Pau, France

\section{Edited by:}

Ian M. Head, Newcastle University, UK

\section{Reviewed by:}

Kathleen Scott, University of South Florida, USA

Guang Gao, Nanjing Institute of Geography and Limnology, China

\section{${ }^{*}$ Correspondence:}

Robert Duran, Equipe Environnement et Microbiologie, Université de Pau et des Pays de I'Adour, IPREM UMR CNRS 5254, BP 1155, 64013 Pau Cedex, France

e-mail: robert.duran@univ-pau.fr
Coastal marine sediments, where important biological processes take place, supply essential ecosystem services. By their location, such ecosystems are particularly exposed to human activities as evidenced by the recent Deepwater Horizon disaster. This catastrophe revealed the importance to better understand the microbial processes involved on hydrocarbon degradation in marine sediments raising strong interests of the scientific community. During the last decade, several studies have shown the key role played by microorganisms in determining the fate of hydrocarbons in oil-polluted sediments but only few have taken into consideration the whole sediment's complexity. Marine coastal sediment ecosystems are characterized by remarkable heterogeneity, owning high biodiversity and are subjected to fluctuations in environmental conditions, especially to important oxygen oscillations due to tides. Thus, for understanding the fate of hydrocarbons in such environments, it is crucial to study microbial activities, taking into account sediment characteristics, physical-chemical factors (electron acceptors, temperature), nutrients, co-metabolites availability as well as sediment's reworking due to bioturbation activities. Key information could be collected from in situ studies, which provide an overview of microbial processes, but it is difficult to integrate all parameters involved. Microcosm experiments allow to dissect in-depth some mechanisms involved in hydrocarbon degradation but exclude environmental complexity. To overcome these lacks, strategies have been developed, by creating experiments as close as possible to environmental conditions, for studying natural microbial communities subjected to oil pollution. We present here a review of these approaches, their results and limitation, as well as the promising future of applying "omics" approaches to characterize indepth microbial communities and metabolic networks involved in hydrocarbon degradation. In addition, we present the main conclusions of our studies in this field.

Keywords: microcosm, mesocosm, molecular ecology, intertidal sediments, experimental ecology, omic's approaches

\section{INTRODUCTION}

Since Amoco Cadiz oil spill in 1978, many other oil spills such as Exxon Valdez (1989), Erika (1999), Prestige (2002), Deepwater Horizon (DH, 2010) have occurred in marine ecosystems. Such oil spill catastrophes generate a lot of indignation among the human populations, especially in coastal areas where environmental injuries are obvious. Cleanup efforts are urgently implemented in order to mitigate the toxic impact of petroleum compounds on the environment. However, the complete recovery of the ecosystem functioning is difficult to achieve because our knowledge on microbial communities, main actors involved in biodegradation processes, is still limited. The main issues regarding marine oil pollution have been already discussed (for review, see McGenity et al., 2012), and microbial processes involved on hydrocarbon degradation extensively described (Timmis etal., 2010; McGenity, 2014). However coastal marine sediments constitute particular ecosystems, especially intertidal zones where environmental conditions are daily modified according to tide level that in turn drive microbial degradation processes (Figure 1A). Although the impact of petroleum on microbial communities resulting in ecological succession, modifications of microbial populations following the hydrocarbon degradation, has been largely demonstrated (Harayama et al., 2004; Bordenave et al., 2004, 2007; Head et al., 2006; Païssé et al., 2008; Nogales etal., 2011) several scientific ecological questions remains to be solved. Among these questions, the organization of microbial community structures facing the presence of spilled oil, the mechanisms involved in their adaptation conducting to efficient hydrocarbon degradation, the structure/function relationship and the contribution of functional redundancy to microbial community resilience are some of the current burning questions which responses, at the applied point of view, will help to conduct appropriate bioremediation strategies such as bio-augmentation and bio-stimulation. The presence of a pollutant, such as petroleum, in the environment highlights also the importance to address academic concerns in microbial ecology, contributing more generally to the ecological theory. The importance to apply theory in microbial ecology has been emphasized by Prosser et al. (2007), especially for addressing population ecology, 


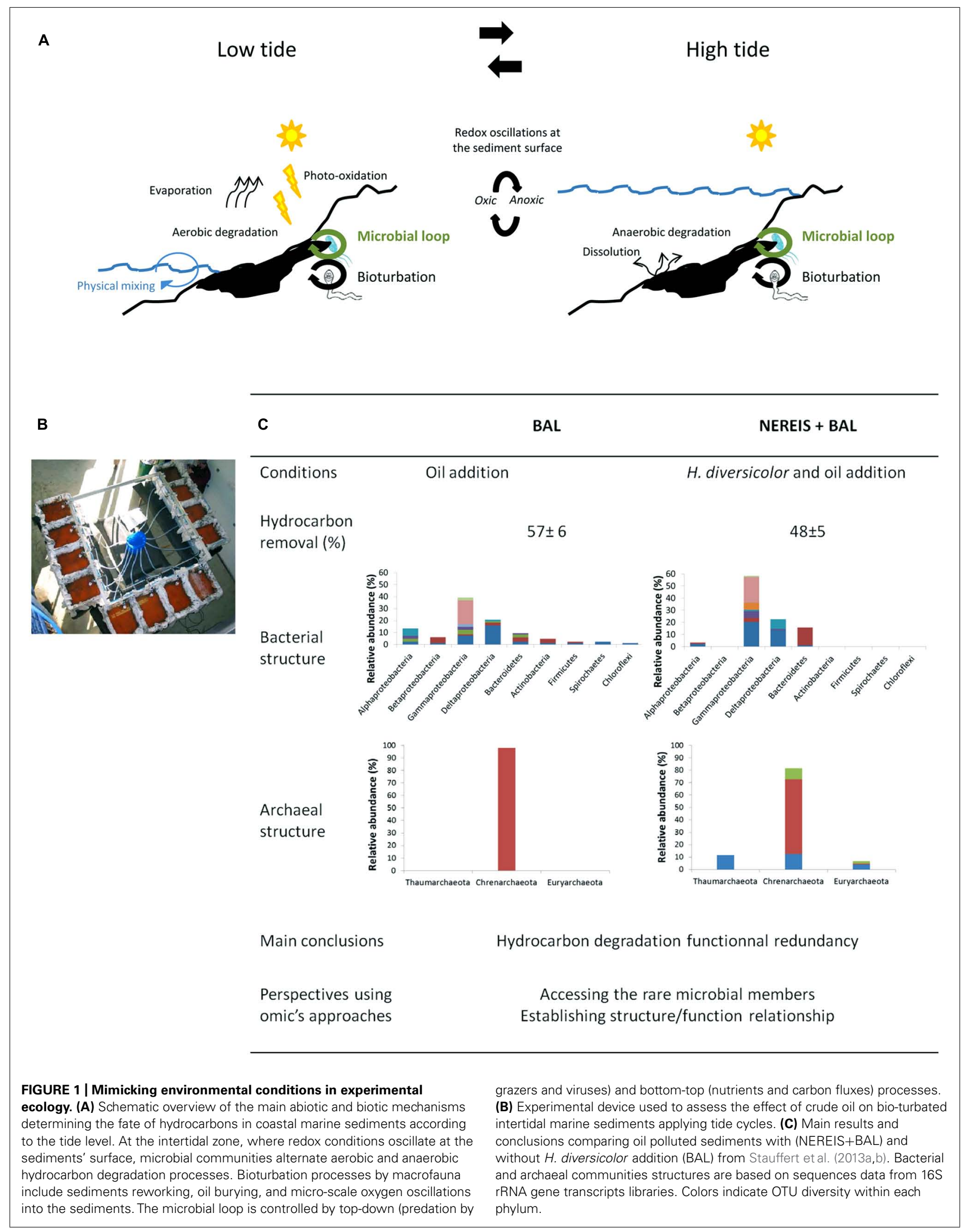


micro-organisms interactions, community assembly and the biodiversity-function relationships. Different approaches including in situ studies and laboratory experiments have been developed in order to test ecological hypothesis, decipher the role of microbial communities in the ecosystem functioning and understand the microbial behavior in front of a pollution. Microbial experimental systems have been particularly useful to address ecological questions by simplifying microbial systems and allowing experimental controls (see reviews by Jessup et al., 2004, 2005). Combined with the recent advances in meta-omics' technologies that provides powerful tools for analyzing microbial communities, their diversity and their functioning as a whole (for review, see Röling et al., 2010; Liu et al., 2013), such experimental microbial systems are promising approaches to gain new insights on functional networks involved in hydrocarbon degradation processes in marine coastal sediments. We review here the recent progress on the ecology of microbial communities involved on hydrocarbon degradation in marine coastal sediments, attained by both in situ and experimental approaches. We present the main conclusions on our work in this field indicating the convenience of using experimental ecology to improve our knowledge in hydrocarbon microbial ecology.

\section{IN SITU MICROBIAL ECOLOGY IN COASTAL MARINE POLLUTED SEDIMENTS}

Opening the microbial black box involved in hydrocarbon degradation needs to take into consideration the whole ecosystem. In situ studies allow to reach the entire microbial communities in their actual context, considering (biotic and abiotic) ecological interactions. Over the past few years, field studies have been performed in marine sediments addressing the impact of oil on microbial communities, by following their organization and/or by characterizing their composition. In most cases this has been approached by spatial comparisons of contrasting contaminated and uncontaminated sites (El-Tarabily, 2002; Miralles et al., 2007, 2010); or sites with different oil contents (LaMontagne et al., 2004; Dias et al., 2011; Iannelli et al., 2012; Kimes et al., 2013). In this way, following the bacterial diversity of oil-polluted retention basin sediments from the Berre lagoon (France) through nine stations, we have demonstrated that bacterial community structure was associated with the gradient of oil contamination (Païssé et al., 2008). Nevertheless, the adaptation of the bacterial community to oil contamination was not characterized by the dominance of oil-degrading bacteria, but a predominance of bacterial populations associated to the sulfur cycle was observed. Other in situ studies have highlighted the presence or the role of sulfur cycle microorganisms in oil-polluted coastal marine sediments, with a focus on sulfate-reducing bacteria (Rosano-Hernandez et al., 2012; Acosta-González et al., 2013). Andrade et al. (2012) suggested that sulfate-reducers constitute a large fraction of the bacteria present in oil-contaminated mangrove sediment. They also demonstrated that abundance of sulfate-reducers decrease with depth and showed greater bacterial abundance and diversity in top layers $(0-5 \mathrm{~cm}$ ) than in deeper layers (below $15 \mathrm{~cm}$ ). Similarly, Acosta-González et al. (2013), applying culture-dependent and molecular techniques to characterize the bacterial populations after the Prestige oil spill at two sampling times (2004 and
2007), reported the dominance of sulfate-reducing bacteria in oilpolluted sediments. Sulfate reduction was the predominant type of respiration connected to hydrocarbon oxidative capacities, and sulfate-reducing bacteria constituted the prevalent populations (being maximal at $12-15 \mathrm{~cm}$ depth). These studies emphasized the ecological importance of sulfate-reducers in oil-polluted marine sediments. Sulfate-reducing microorganisms are known to play a key role in coastal marine ecosystems by recycling the organic matter (Jorgensen, 1982), even after an oil-spill. Acosta-González et al. (2013) also demonstrated that community structure was initially dominated by Gamma and Deltaproteobacteria (2004), while 3 years late, in 2007, the phylum Bacteroidetes was a main component of the community. These results, showing the great plasticity of bacterial community structures and suggesting that they were constantly adapting to the changing environmental factors, highlight the importance to consider the impact of environmental parameters on microorganisms when studying oil degradation in coastal marine sediments. In this way Kostka et al. (2011), considering spatial-temporal variations in oil-contaminated beach ecosystems, showed the selective response of bacterial communities to oil from the DH oil spill. Microbial communities were dominated by members of the Gammaproteobacteria and Alphaproteobacteria, suggested as key players in oil-degradation. These groups are constituted by hydrocarbon-degrading members, the former contributing to the early stages of oil hydrocarbon degradation (oxidizing more reactive components such as $n$-alkanes), and the latter contributing to the later stages of degradation (oxidizing more recalcitrant compounds such as PAHs). In the same way, examining microbial response to $\mathrm{DH}$ oil spill in coastal sediments, Horel et al. (2012) showed no seasonal differences in the abundances of total hydrocarbon and alkane degraders in marsh ecosystem with high physical-chemical parameters variations.

Different molecular approaches, mainly involving 16S rRNA gene analyses such as DGGE (LaMontagne et al., 2004; Al-Thukair et al., 2007; Dias etal., 2011; Andrade et al., 2012; Isaac et al., 2013) or T-RFLP (Edlund and Jansson, 2006; Païssé et al., 2008; Iannelli etal., 2012), clone libraries (LaMontagne et al., 2004; Miralles etal., 2007, 2010), and phylo/geochip (Beazley et al., 2012), were used to describe the microbial communities established in oil-polluted coastal environments. More recently, NGS and "omics" approaches have been applied, allowing to in-depth characterization of microbial communities (Kostka et al., 2011).

These studies allowed to assess the complexity of autochthonous microbial communities related to the oil pollution, revealing in situ changes in microbial diversity and their selective response to the presence of oil. Nevertheless, in situ approaches have many drawbacks since information access on ecophysiology of oil-degrading microorganisms, their activity and degradation pathways remain still limited.

\section{EXPERIMENTAL ECOLOGY APPROACHES IN MARINE COASTAL SEDIMENTS STUDIES}

Experimental approaches have been developed to address the ecological role of microbial communities on hydrocarbon mitigation in marine sediments. These approaches have progressed as scientific questions arise with the concomitant advances of 
microbial molecular ecology techniques. Enrichment cultures (or slurries), similar approaches to those used for microbial strains isolation, have been used to tackle the impact of crude oil and petroleum hydrocarbon compounds on bacterial communities. Usually, sediments are mixed with a minimal medium (more often artificial sea water) containing crude oil or selected hydrocarbon compounds, and maintained at laboratory under agitation. Following the dynamic modifications of microbial communities in the slurries, fingerprinting techniques and 16S rRNA gene libraries analyses have shown the ecological succession of microbial populations in response to hydrocarbon compounds in pristine deep marine sediments (Cui et al., 2008), mangrove sediments (dos Santos etal., 2011), polluted harbor marine sediments (Wang and Tam, 2011; Dell'Anno etal., 2012; Rocchetti et al., 2012) and anoxic zone of microbial mats (Abed et al., 2011). While such approaches were useful to estimate the microbial degradation capacities of hydrocarbon compounds (Cui et al., 2008; Abed etal., 2011), the efficiency of bioremediation strategies (Dell'Anno et al., 2012) and the early functional response involved on hydrocarbon degradation (Paisse etal., 2011; Paissé etal., 2012), the simplification of the microbial systems present some limitations. Among them, the destruction of the sediments' structure imposes a strong limit to extrapolation to complex systems where microorganisms interact each other and with surrounding organisms according to the structure and stratification of sediments. To overcome these limitations, microcosms maintaining intact the sediment structure have been developed. An elegant example is provided by studies undertaken to determine the impact of crude oil on microbial mats (Bordenave et al., 2004, 2007; Lliros et al., 2008). Microbial mats are vertically stratified structures where microbial populations take place according to micro-gradients of oxygen, sulfur and light at the water-sediment interface. Pieces of microbial mats are maintained in microcosms under diel light-dark cycle $(16 \mathrm{~h} / 8 \mathrm{~h})$ to ensure the microbial stratification and then exposed to crude oil. Our studies with microbial mats from Camargue (France) demonstrated, by combining T-RFLP and 16S rRNA (gene and transcript) library analyses, the dynamic changes of microbial communities inhabiting microbial mats in response to Erika fuel with concomitant degradation of hydrocarbon compounds (Bordenave etal., 2004) and their resilience after 1 year exposure (Bordenave et al., 2007). Lliros et al. (2008) showed the versatility of such microbial communities by demonstrating that microbial communities had distinct behavior according to the type of crude oil using reconstituted microbial mats from the Ebro delta (Spain) maintained under tidal cycles without renewing water. Microbial mats constitute particular ecosystems relatively easy to maintain in microcosms under their initial stratification because they are ecosystems driven by phototrophic microorganisms that impose a selective pressure. In comparison, marine coastal sediments are more susceptible to the fluctuation of environmental parameters due to tide and waves. Thus, the environmental conditions in which they develop are more difficult to simulate. Experimental systems maintaining sediments with tide simulation such as sediment columns (Röling et al., 2002) and sediments maintained in aquarium (Taketani et al., 2010) allowed to determine the role of nutrients bio-stimulation treatments on hydrocarbon-degradation efficiency and the impact of crude oil addition on adapted nitrogen fixation populations, respectively. But, because sediments were homogenized prior microcosms setting, these studies simulate mainly chemical-physical environmental parameters without addressing the impact of the other benthic organisms. In order to further maintain sediments as closer as possible to environmental parameters different strategies have been developed. Katayama et al. (2003) maintaining sediments in a tidal flat simulator, with a wave generator and a tide control device, identified oil-susceptible bacteria as bio-indicator of pollution by combining culture-dependent and molecular approaches. Suárez-Suárez et al. (2011) installed mesocosms in situ to assess the role of sulfate reducing bacteria in the degradation of Prestige oil. Similarly, Coulon et al. (2012), maintaining intact cores of coastal mudflat sediments in mesocosms under tidal cycles without renewing water, observed the development of phototrophic biofilm playing a crucial role in hydrocarbon degradation. They also demonstrated the negative effect of oil on the benthic macrofauna that in turn allowed the development of phototrophic biofilm (Chronopoulou et al., 2013). This observation highlights the importance to consider sediments as a whole ecosystem where microbial activities involved on hydrocarbon degradation are driven not only by the presence of contaminant but also by biotic and abiotic factors controlling the microbial web functioning. Appropriate experimental ecology approaches would be useful to decipher the mechanisms determining the organization of microbial communities with efficient hydrocarbon degradation capacities. In the next section we present the experimental approach developed in our lab to address the effect of the reworking activity of the benthic macrofauna (bioturbation) in structuring hydrocarbon-degrading microbial communities and the main results obtained.

\section{MIMICKING ENVIRONMENTAL CONDITIONS IN EXPERIMENTAL ECOLOGY}

In intertidal zones, microbial degradation processes are driven by environmental conditions that are daily modified according to tide level (Figure 1A). An original microcosm (Figure 1B) system maintaining the structure of muddy sediments under tidal cycles was set up ensuring conditions close to those prevailing in the natural environment of coastal marine sediments (Stauffert etal., 2013a). Coastal marine sediments were sampled with a core collector, and transferred while maintaining their integrity into microcosm boxes. Tidal cycles were applied and natural seawater was renewed with each tidal cycle. The experimental design was drawn with the aim to test the hypothesis that the addition of polychaetes stimulates the bioturbation activity which in turn could select a particular microbial community with an increased biodegradation capability. The conditions applied were: (i) CTRL: control condition, (ii) BAL: oil addition, (iii) NEREIS: addition of Hediste (Nereis) diversicolor and (iv) NEREIS+BAL, addition of oil and $H$. diversicolor. Oil contamination was performed on the surface (2 $\mathrm{cm}$ top layer) after homogenization with sediments (BAL and NEREIS+BAL). $H$. diversicolor was added to the microcosms in order to increase sediments reworking (NEREIS and NEREIS+BAL). By following, over a 9-month period, the petroleum removal, the macrofaunal 
reworking activity and the microbial communities' structures and compositions, we demonstrated that the modification of the microbial community structure in mudflat sediments after petroleum addition was dependent on the presence of the added burrowing polychaetes $H$. diversicolor (Stauffert et al., 2013a,b). Contrary to our initial hypothesis, despite that the addition of burrowing organisms stimulated the bioturbation activity and modified the microbial community structure, the overall oil removal capacity was not affected by the addition of polychaetes. For Bacteria (Figure 1C), although both BAL and NEREIS+BAL communities were dominated by Gammaand Delta-proteobacteria, important differences were observed at the genus level. The BAL community showed more diversity with the presence of minor phyla and a slight increase of Alpha-proteobacteria (Stauffert etal., 2013a). For Archaea (Figure 1B), BAL community was represented only by Crenarchaeota MCG members while NEREIS+BAL community exhibited more diversity (Stauffert et al., 2013b). Thus, from an initial microbial community two distinct communities showing a similar overall oil removal capacity were obtained. By adding burrowing organisms to sediments maintained nearenvironmental conditions we were able to manipulate microbial community structure and composition, opening the way for the study of the mechanisms underlying microbial community restructuring after environmental perturbations which includes resistance, resilience, and functional redundancy (Allison and Martiny, 2008). Combining metagenomic and metatranscriptomic analyses with metabolite profiling will provide valuable information to understand the mechanisms underpinning the bacterial communities structuring, particularly the role of the rare microbial members in the establishment of structure/function relationship. Such approach has demonstrated the influence of hydrocarbon compounds on the microbial community inhabiting the deep-sea sediments of the Gulf of Mexico after $\mathrm{DH}$ oil spill (Kimes et al., 2013). The application of correlation and co-occurrence analyzes from metagenomics and 16S bar-coding

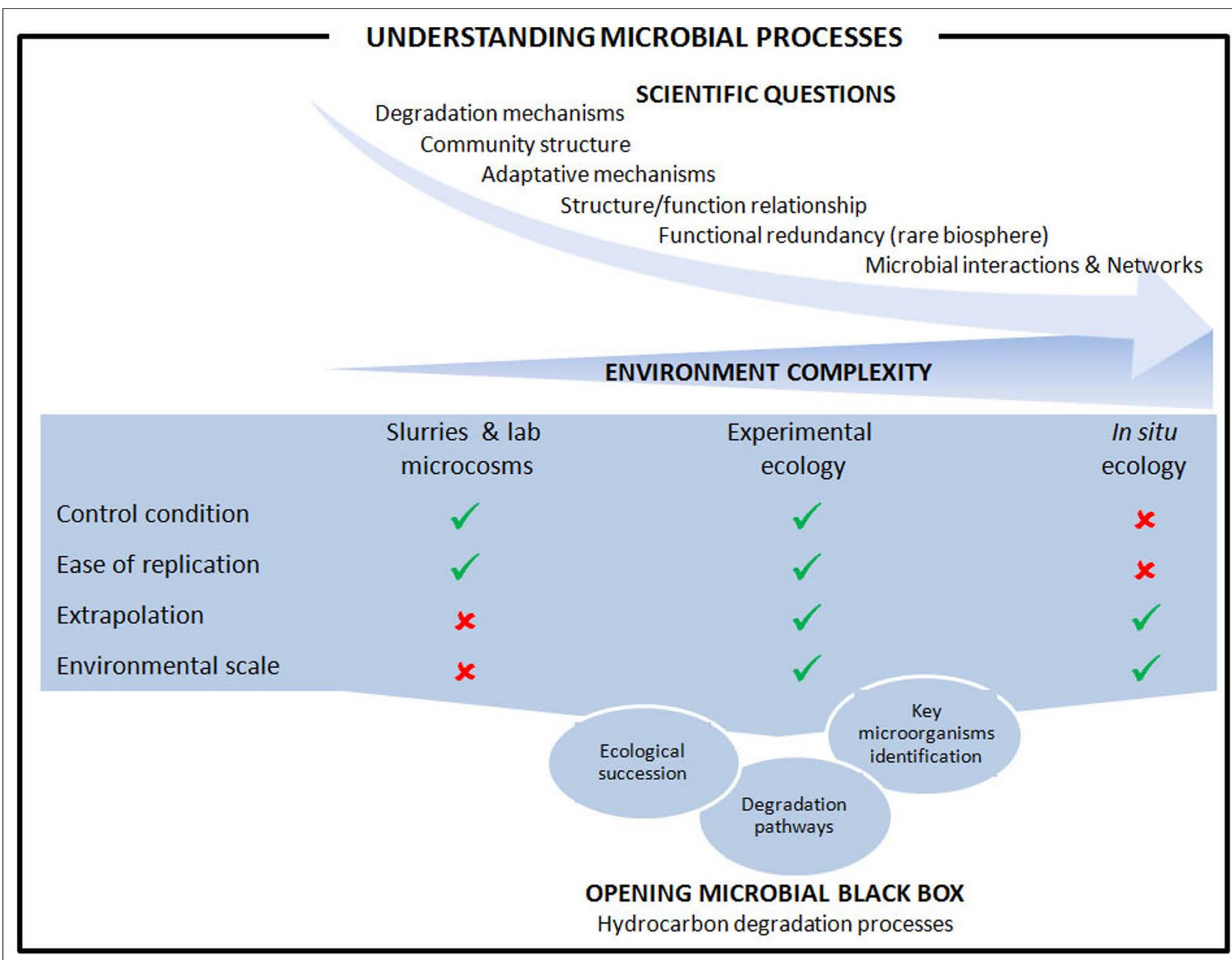

FIGURE 2 | Understanding microbial processes involved on hydrocarbon degradation in marine coastal sediments. The general scheme from scientific questions to microbial processes is presented together with the comparison of experimental approaches developed at different environmental complexity. 
profiling, that allows to forecast microbial interactions and metabolic networks (Faust and Raes, 2012), to experimental systems may offer the possibility to gain in depth information on how microbial communities behave after a disturbance (Shade et al., 2010; Knight et al., 2012) and define a "core" community ensuring the basal ecosystem functioning. Experimental systems authorize comparative metatranscriptomics approaches (Bordenave etal., 2009, 2010) that combined with high-throughput sequencing can provide the discovery of novel genes expressed during phytoplankton bloom with the possibility to explore the structure/function relationships (Gilbert et al., 2008). Another example of metatranscriptomic analysis is the identification of a set of genes, including hydrocarbon degradation, stress response and detoxification genes, induced after the environmental disturbance by phenanthrene in soil microcosms (de Menezes et al., 2012). The structure/function relationship can be further elucidated by metaproteomics, enabling the identification of proteins present in the community. The metaproteogenomic approach, that combine metagenomic and metaproteomic analyzes, allowed to describe the metabolism related to naphthalene degradation in soil by comparing four microbial communities maintained in microcosms (Guazzaroni et al., 2013). However, metaproteomics needs further development involving mass spectrometers with high sensitivity to access low abundant proteins (Zarraonaindia et al., 2013). Our microcosm system allows to propose an experimental ecology approach to determine how the fluctuation of environmental parameters, particularly oxygenation and redox oscillations resulting from the biological (bio-turbation) or mechanical (physical-turbation) reworking of the sediment, influence the coupling between bacterial functional groups and their degradation capacities.

\section{CONCLUDING REMARKS}

We reviewed here recent approaches implemented in order to assess microbial processes involved on hydrocarbon degradation in marine coastal sediments. Microbiologists have developed several approaches, including more or less sophisticated experimental systems and in situ studies to answer the scientific questions regarding the microbial mechanisms that take place in response to oil and hydrocarbon contaminations. Figure 2 summarize the main advantage and limitations for the approach considered in addressing the scientific questions. Experimental ecology using experimental systems mimicking as close as possible the environmental conditions combine the advantages of lab controlled systems with the possibility of extrapolation to the real situation found in complex ecosystems. Such approaches offer the opportunity to conduct experiments in replicates, crucial advantage for robust statistical analyses as highlighted by Prosser (2010). The advent of next generation sequencing technologies combined with high-throughput methods assessing functionality (proteomics and metabolomics) has allowed the development of systems biology, a holistic approach to understand complex biological systems. However, because the sediments' ecology in coastal areas is extremely complex, analysis using system biology tools at different environmental scales would be useful to elucidate microbial hydrocarbon degradation processes.

\section{ACKNOWLEDGMENTS}

This research was funded by the French National Agency (ANR) under the DHYVA (ANR 2006 SEST 09) and DECAPAGE (ANR 2011 CESA 006 01) projects. We would like to thank the CEDRE for the setup of the microcosms and all partners of the DHYVA and DECAPAGE project for their useful discussions. We acknowledge the Regional Platform for Environmental Microbiology PREMICE supported by the Aquitaine Regional Government Council (France).

\section{REFERENCES}

Abed, R. M. M., Musat, N., Musat, F., and Mußmann, M. (2011). Structure of microbial communities and hydrocarbon-dependent sulfate reduction in the anoxic layer of a polluted microbial mat. Mar. Pollut. Bull. 62, 539-546. doi: 10.1016/j.marpolbul.2010.11.030

Acosta-González, A., Rosselló-Móra, R., and Marqués, S. (2013). Characterization of the anaerobic microbial community in oil-polluted subtidal sediments: aromatic biodegradation potential after the Prestige oil spill. Environ. Microbiol. 15, 77-92. doi: 10.1111/j.1462-2920.2012.02782.x

Allison, S. D., and Martiny, J. B. H. (2008). Resistance, resilience, and redundancy in microbial communities. Proc. Natl. Acad. Sci. U.S.A 105, 11512-11519. doi: 10.1073/pnas.0801925105

Al-Thukair, A. A., Abed, R. M. M., and Mohamed, L. (2007). Microbial community of cyanobacteria mats in the intertidal zone of oil-polluted coast of Saudi Arabia. Mar. Pollut. Bull. 54, 173-179. doi: 10.1016/j.marpolbul.2006.08.043

Andrade, L. L., Leite, D. C. A., Ferreira, E. M., Ferreira, L. Q., Paula, G. R., Maguire, M. J., et al. (2012). Microbial diversity and anaerobic hydrocarbon degradation potential in an oil-contaminated mangrove sediment. BMC Microbiol. 12:186. doi: 10.1186/1471-2180-12-186

Beazley, M. J., Martinez, R. J., Rajan, S., Powell, J., Piceno, Y. M., Tom, L. M., et al. (2012). Microbial community analysis of a coastal salt marsh affected by the deepwater horizon oil spill. PLoS ONE 7:e41305. doi: 10.1371/journal.pone.0041305

Bordenave, S., Fourçans, A., Blanchard, S., Goni-Urriza, M. S., Caumette, P., and Duran, R. (2004). Structure and functional analyses of bacterial communities changes in microbial mats following petroleum exposure. Ophelia 58, 195-203. doi: 10.1080/00785236.2004.10410227

Bordenave, S., Goñi-Urriza, M., Caumette, P., and Duran, R. (2009). Differential display analysis of cdna involved in microbial mats response after heavy fuel oil contamination. J. Microb. Biochem. Technol. 1, 1-4. doi: 10.4172/1948-5948.1000001

Bordenave, S., Goñi-Urriza, M. S., Caumette, P., and Duran, R. (2007). Effects of heavy fuel oil on the bacterial community structure of a pristine microbial mat. Appl. Environ. Microbiol. 73, 6089-6097. doi: 10.1128/AEM.01352-07

Bordenave, S., Goñi-Urriza, M. S., and Duran, R. (2010). "Assessing functionality by differential display and RNA arbitrary PCR," in Handbook of Hydrocarbon and Lipid Microbiology, ed. K. N. Timmis (Heidelberg: Springer-Verlag ), 4051-4061. doi: 10.1007/978-3-540-77587-4_315

Chronopoulou, P. M., Fahy, A., Coulon, F., Païssé, S., Goñi Urriza, M., Acuña Alvarez, L., et al. (2013). Impact of a simulated oil spill on benthic phototrophs and nitrogen-fixing bacteria in mudflat mesocosms. Environ. Microbiol. 15, 242-252. doi: 10.1111/j.1462-2920.2012.02864.x

Coulon, F., Chronopoulou, P.-M., Fahy, A., Sandrine, P., Goñi-Urriza, M., Peperzak, L., et al. (2012). Central role of dynamic tidal biofilms dominated by aerobic hydrocarbonoclastic bacteria and diatoms in the biodegradation of hydrocarbons in coastal mudflats. Appl. Environ. Microbiol. 78, 3638-3648. doi: 10.1128/AEM.00072-12

Cui, Z. S., Lai, Q. L., Dong, C. M., and Shao, Z. Z. (2008). Biodiversity of polycyclic aromatic hydrocarbon-degrading bacteria from deep sea sediments of the Middle Atlantic Ridge. Environ. Microbiol. 10, 2138-2149. doi: 10.1111/j.1462-2920.2008.01637.x

Dell'Anno, A., Beolchini, F., Rocchetti, L., Luna, G. M., and Danavaro, R. (2012). High bacterial biodiversity increases degradation performance of hydrocarbons during bioremediation of contaminated harbor marine sediments. Environ. Pollut. 167, 85-92. doi: 10.1016/j.envpol.2012.03.043

de Menezes, A., Clipson, N., and Doyle, E. (2012). Comparative metatranscriptomics reveals widespread community responses during phenanthrene degradation 
in soil. Environ. Microbiol. 14, 2577-2588. doi: 10.1111/j.1462-2920.2012. 02781.x

Dias, A. C. F., Dini-Andreote, F., Taketani, R. G., Tsai, S. M., Azevedo, J. L., De Melo, I. S., et al. (2011). Archaeal communities in the sediments of three contrasting mangroves. J. Soils Sediments 11, 1466-1476. doi: 10.1007/s11368-011-0423-7

dos Santos, H. F., Cury, J. C., Do Carmo, F. L., Dos Santos, A. L., Tiedje, J., Van Elsas, J. D., et al. (2011). Mangrove bacterial diversity and the impact of oil contamination revealed by pyrosequencing: bacterial proxies for oil pollution. PLoS ONE 6:e16943. doi: 10.1371/journal.pone.0016943

Edlund, A., and Jansson, J. K. (2006). Changes in active bacterial communities before and after dredging of highly polluted Baltic Sea sediments. Appl. Environ. Microbiol. 72, 6800-6807. doi: 10.1128/AEM.00971-06

El-Tarabily, K. A. (2002). Total microbial activity and microbial composition of a mangrove sediment are reduced by oil pollution at a site in the Arabian Gulf. Can. J. Microbiol. 48, 176-182. doi: 10.1139/w01-140

Faust, K., and Raes, J. (2012). Microbial interactions: from networks to models. Nat. Rev. Microbiol. 10, 538-550. doi: 10.1038/nrmicro2832

Gilbert, J. A., Field, D., Huang, Y., Edwards, R., Li, W. Z., Gilna, P., et al. (2008). Detection of large numbers of novel sequences in the metatranscriptomes of complex marine microbial communities. PLoS ONE 3:e3042. doi: 10.1371/journal.pone.0003042

Guazzaroni, M. E., Herbst, F. A., Lores, I., Tamames, J., Pelaez, A. I., LopezCortes, N., et al. (2013). Metaproteogenomic insights beyond bacterial response to naphthalene exposure and bio-stimulation. ISME J. 7, 122-136. doi: 10.1038/ismej.2012.82

Harayama, S., Kasai, Y., and Hara, A. (2004). Microbial communities in oil-contaminated seawater. Curr. Opin. Biotechnol. 15, 205-214. doi 10.1016/j.copbio.2004.04.002

Head, I. M., Jones, D. M., and Röling, W. F. (2006). Marine microorganisms make a meal of oil. Nat. Rev. Microbiol. 4, 173-182. doi: 10.1038/nrmicro1348

Horel, A., Mortazavi, B., and Sobecky, P. A. (2012). Seasonal monitoring of hydrocarbon degraders in Alabama marine ecosystems following the deepwater horizon oil spill. Water Air Soil Poll. 223, 3145-3154. doi: 10.1007/s11270-012-1 097-5

Iannelli, R., Bianchi, V., Macci, C., Peruzzi, E., Chiellini, C., Petroni, G., et al. (2012). Assessment of pollution impact on biological activity and structure of seabed bacterial communities in the Port of Livorno (Italy). Sci. Total Environ. 426, 56-64. doi: 10.1016/j.scitotenv.2012.03.033

Isaac, P., Sanchez, L. A., Bourguignon, N., Cabral, M. E., and Ferrero, M. A. (2013). Indigenous PAH-degrading bacteria from oil-polluted sediments in Caleta Cordova, Patagonia Argentina. Int. Biodeterior. Biodegradation 82, 207-214. doi: 10.1016/j.ibiod.2013.03.009

Jessup, C. M., Forde, S. E., and Bohannan, B. J. M. (2005). Microbial experimental systems in ecology. Adv. Ecol. Res., 37, 273-307. doi: 10.1016/S00652504(04)37009-1

Jessup, C. M., Kassen, R., Forde, S. E., Kerr, B., Buckling, A., Rainey, P. B., et al. (2004). Big questions, small worlds: microbial model systems in ecology. Trends Ecol. Evol. 19, 189-197. doi: 10.1016/j.tree.2004.01.008

Jorgensen, B. B. (1982). Mineralization of organic matter in the sea bed[mdash] the role of sulphate reduction. Nature 296, 643-645. doi: 10.1038/296643a0

Katayama, Y., Oura, T., Iizuka, M., Orita, I., Cho, K. J., Chung, I. Y., et al. (2003). Effects of spilled oil on microbial communities in a tidal flat. Mar. Pollut. Bull. 47, 85-90. doi: 10.1016/S0025-326X(03)00103-6

Kimes, N. E., Callaghan, A. V., Aktas, D. F., Smith, W. L., Sunner, J., Golding, B. T., et al. (2013). Metagenomic analysis and metabolite profiling of deep-sea sediments from the Gulf of Mexico following the Deepwater Horizon oil spill. Front. Microbiol. 4:50. doi: 10.3389/fmicb.2013.00050

Knight, R., Jansson, J., Field, D., Fierer, N., Desai, N., Fuhrman, J. A., et al. (2012). Unlocking the potential of metagenomics through replicated experimental design. Nat. Biotechnol. 30, 513-520. doi: 10.1038/nbt.2235

Kostka, J. E., Prakash, O., Overholt, W. A., Green, S. J., Freyer, G., Canion, A., et al. (2011). Hydrocarbon-degrading bacteria and the bacterial community response in gulf of Mexico beach sands impacted by the deepwater horizon oil spill. Appl. Environ. Microbiol. 77, 7962-7974. doi: 10.1128/AEM. 05402-11

LaMontagne, M. G., Leifer, I., Bergmann, S., Van De Werfhorst, L. C., and Holden, P. A. (2004). Bacterial diversity in marine hydrocarbon seep sediments. Environ. Microbiol. 6, 799-808. doi: 10.1111/j.1462-2920.2004.00613.x
Liu, D., Hoynes-O'connor, A., and Zhang, F. (2013). Bridging the gap between systems biology and synthetic biology. Front. Microbiol. 4:211. doi: 10.3389/fmicb.2013.00211

Lliros, M., Gaju, N., De Oteyza, T. G., Grimalt, J. O., Esteve, I., and MartinezAlonso, M. (2008). Microcosm experiments of oil degradation by microbial mats. II. The changes in microbial species. Sci. Total Environ. 393, 39-49. doi: 10.1016/j.scitotenv.2007.11.034

McGenity, T. J. (2014). Hydrocarbon biodegradation in intertidal wetland sediments. Curr. Opin. Biotechnol. 27, 46-54. doi: 10.1016/j.copbio.2013.10.010

McGenity, T. J., Folwell, B. D., Mckew, B., and Sanni, G. O. (2012). Marine crude-oil biodegradation: a central role for interspecies interactions. Aquat. Biosyst. 8:10. doi: 10.1186/2046-9063-8-10

Miralles, G., Acquaviva, M., Bertrand, J. C., and Cuny, P. (2010). Response of an archaeal community from anoxic coastal marine sediments To experimental petroleum contamination. Aquat. Microb. Ecol. 59, 25-31. doi: 10.3354/ame 01379

Miralles, G., Nérini, D., Manté, C., Acquaviva, M., Doumenq, P., Michotey, V., et al. (2007). Effects of spilled oil on bacterial communities of Mediterranean coastal anoxic sediments chronically subjected to oil hydrocarbon contamination. Microb. Ecol. 54, 646-661. doi: 10.1007/s00248-007-9 221-6

Nogales, B., Lanfranconi, M. P., Piña-Villalonga, J. M., and Bosch, R. (2011). Anthropogenic perturbations in marine microbial communities. FEMS Microbiol. Rev. 35, 275-298. doi: 10.1111/j.1574-6976.2010.00248.x

Païssé, S., Coulon, F., Goñi Urriza, M., Peperzak, L., Mcgenity, T. J., and Duran, R. (2008). Structure of bacterial communities along a hydrocarbon contamination gradient in a coastal sediment. FEMS Microbiol. Rev. 66, 295-305. doi: 10.1111/j.1574-6941.2008.00589.x

Paisse, S., Duran, R., Coulon, F., and Goñi-Urriza, M. (2011). Are alkane hydroxylase genes (alkB) relevant to assess petroleum bioremediation processes in chronically polluted coastal sediments? Appl. Microbiol. Biotechnol. 92, 835-844. doi: 10.1007/s00253-011-3381-5

Paissé, S., Goñi-Urriza, M., Stadler, T., Budzinski, H., and Duran, R. (2012). Ring-hydroxylating dioxygenase (RHD) expression in a microbial community during the early response to oil pollution. FEMS Microbiol. Ecol. 80, 77-86. doi: 10.1111/j.1574-6941.2011.01270.x

Prosser, J. I. (2010). Replicate or lie. Environ. Microbiol. 12, 1806-1810. doi: 10.1111/j.1462-2920.2010.02201.x

Prosser, J. I., Bohannan, B. J. M., Curtis, T. P., Ellis, R. J., Firestone, M. K., Freckleton, R. P., et al. (2007). Essay - the role of ecological theory in microbial ecology. Nat. Rev. Microbiol. 5, 384-392. doi: 10.1038/nrmicro1643

Rocchetti, L., Beolchini, F., Hallberg, K. B., Johnson, D. B., and Dell'anno, A. (2012). Effects of prokaryotic diversity changes on hydrocarbon degradation rates and metal partitioning during bioremediation of contaminated anoxic marine sediments. Mar. Pollut. Bull. 64, 1688-1698. doi: 10.1016/j.marpolbul.2012. 05.038

Röling, W. F. M., Ferrer, M., and Golyshin, P. N. (2010). Systems approaches to microbial communities and their functioning. Curr. Opin. Biotechnol 21, 532538. doi: 10.1016/j.copbio.2010.06.007

Röling, W. F. M., Milner, M. G., Jones, D. M., Lee, K., Daniel, F., Swannell, R. J. P., etal. (2002). Robust hydrocarbon degradation and dynamics of bacterial communities during nutrient-enhanced oil spill bioremediation. Appl. Environ. Microbiol. 68, 5537-5548. doi: 10.1128/AEM.68.11.5537-55 48.2002

Rosano-Hernandez, M. C., Ramirez-Saad, H., and Fernandez-Linares, L. (2012). Petroleum-influenced beach sediments of the Campeche Bank, Mexico: diversity and bacterial community structure assessment. J. Environ. Manage. 95, S32-S331. doi: 10.1016/j.jenvman.2011.06.046

Shade, A., Chiu, C. Y., and Mcmahon, K. D. (2010). Differential bacterial dynamics promote emergent community robustness to lake mixing: an epilimnion to hypolimnion transplant experiment. Environ. Microbiol. 12, 455-466. doi: 10.1111/j.1462-2920.2009.02087.x

Stauffert, M., Cravo-Laureau, C., Jézéquel, R., Barantal, S., Cuny, P., Gilbert, F., et al. (2013a). Impact of oil on bacterial community structure in bioturbated sediments. PLoS ONE 8:e65347. doi: 10.1371/journal.pone.0065347

Stauffert, M., Duran, R., Gassie, C., and Cravo-Laureau, C. (2013b). Response of archaeal communities to oil spill in bioturbated mudflat sediments. Microb. Ecol. 1-12. doi: 10.1007/s00248-013-0288-y 
Suárez-Suárez, A., López-López, A., Tovar-Sánchez, A., Yarza, P., Orfila, A., Terrados, J., et al. (2011). Response of sulfate-reducing bacteria to an artificial oil-spill in a coastal marine sediment. Environ. Microbiol. 13, 1488-1499. doi: 10.1111/j.14622920.2011.02451.x

Taketani, R. G., Franco, N. O., Rosado, A. S., and Van Elsas, J. D. (2010). Microbial community response to a simulated hydrocarbon spill in mangrove sediments. $J$. Microbiol. 48, 7-15. doi: 10.1007/s12275-009-0147-1

Timmis, K. N., Mcgenity, T. J., Meer, J. R., and Lorenzo, V. (2010). Handbook of Hydrocarbon and Lipid Microbiology. Heidelberg: Springer-Verlag. doi: 10.1007/978-3-540-77587-4

Wang, Y. F., and Tam, N. F. Y. (2011). Microbial community dynamics and biodegradation of polycyclic aromatic hydrocarbons in polluted marine sediments in Hong Kong. Mar. Pollut. Bull. 63, 424-430. doi: 10.1016/j.marpolbul.2011. 04.046

Zarraonaindia, I., Smith, D. P., and Gilbert, J. A. (2013). Beyond the genome: community-level analysis of the microbial world. Biol. Philos. 28, 261-282. doi $10.1007 /$ s10539-012-9357-8
Conflict of Interest Statement: The authors declare that the research was conducted in the absence of any commercial or financial relationships that could be construed as a potential conflict of interest.

Received: 31 October 2013; accepted: 21 January 2014; published online: 12 February 2014.

Citation: Cravo-Laureau $C$ and Duran $R$ (2014) Marine coastal sediments microbial hydrocarbon degradation processes: contribution of experimental ecology in the omics'era. Front. Microbiol. 5:39. doi: 10.3389/fmicb.2014.00039

This article was submitted to Aquatic Microbiology, a section of the journal Frontiers in Microbiology.

Copyright (c) 2014 Cravo-Laureau and Duran. This is an open-access article distributed under the terms of the Creative Commons Attribution License (CC BY). The use, distribution or reproduction in other forums is permitted, provided the original author(s) or licensor are credited and that the original publication in this journal is cited, in accordance with accepted academic practice. No use, distribution or reproduction is permitted which does not comply with these terms. 